\title{
Placement of BMPs in urban catchment area using SUSTAIN model: case study at Universitas Indonesia Campus, Depok, West Java, Indonesia
}

\author{
Tina Kesuma Warganda ${ }^{1, *}$, and Dwita Sutjiningsih ${ }^{1}$ \\ ${ }^{1}$ Civil Engineering Department, Universitas Indonesia, 16424 Depok, Indonesia
}

\begin{abstract}
Aquatic system quality degradation by urban runoff owing to the effect of increasing impervious cover due to urbanization is becoming a serious issue. Based on 2015 data, with total imperviousness more than $60 \%$ in aquatic system catchment area of Universitas Indonesia (UI) Campus, the aquatic system quality is in poor condition. Best Management Practices (BMPs) as the practical form of Low Impact Development (LID) concept are proposed to be implemented in the catchment area. The performance of BMPs implementation can be quantitatively assessed using System for Urban Stormwater Treatment and Analysis Integration (SUSTAIN) model developed by US Environmental Protection Agency. As a decision support system, SUSTAIN model as the extension of ArcGIS can be applied for placement of BMPs at strategic locations in urban watersheds. This study aims to find the suitable location of BMPs placement in nine sub-catchments of UI Campus aquatic system catchment area. The suitability criteria for placing structural BMPs comprise nine database layers including slope, soil type, urban land use, percent impervious, land ownership, roads, water table depth, stream location, and drainage area. The study shows that there are ten types of BMPs that suitable to be implemented in UI campus catchment area, while three types of BMPs are not suitable. Based on the validation analysis, the applicable result from SUSTAIN model is 18 of 20, or has 90 percent of trust.
\end{abstract}

\section{Introduction}

A decrease in the quality of aquatic systems due to rainwater runoff in urban areas as a result of the increasing extent of impervious cover (IC) due to urbanization has become a very serious problem. The development of an urban area is always accompanied by an increase in population, activities and land needs, both for economic activities and settlements to meet the human needs. The conditions of land constraints result in urban activity intervention on land that should function as conservation areas and green open spaces. As a result, the number of impervious cover (IC) is increased, infiltration areas are

\footnotetext{
* Corresponding author: tina_kesuma@yahoo.com
} 
getting narrower resulting in increased surface flow and erosion that ultimately lead to the degradation of water quality $[3,5,7-9,12,15]$.

The relationship between IC and water quality mentioned that the quality of an aquatic system of a catchment area can be indicated based on the percentage of its impervious cover from total CA $[3,5,7-9,15]$. Referring to that theory, based on 2015 data, with a total impervious cover of $60 \%$ [8] within the Catchment Area (CA) of the Universitas Indonesia (UI) $[2,8]$, Depok, its CA aquatic system is in a range of impacted and heavily damaged condition $[8,15]$.

Refering to the understanding of the relationship between IC with the water quality degradation mentioned, a Low Impact Development (LID) approach is highly required for site development of catchment area [10]. LID is intended to preserve or reinstate the natural, pre-developed condition of an urban site to maximize on-site stormwater controls $[10,13]$. As components of LID, structural Best Management Practices (BMPs) are designed to prevent, control or treat stormwater discharges. LID/BMPs integrate smallscale measures (e.g., bioretention or rain garden, porous pavement, grassed swale, green roof, rain barrel or cistern, vegetated filterstrip, infiltration basin, constructed wetland, etc.) scattered throughout the urban site [10].

One of the most important thing in determining the successful application of LID in a $\mathrm{CA}$ is in determining the suitable site or location for placing the BMPs, in order for the BMPs to function optimally $[4,10,11,14]$. In a catchment area with a complex variations of land use, such as urban areas with high density of buildings, and still developing like CA in Universitas Indonesia campus, the decision to choose the suitable location becomes more complicated compared to areas with lower building density. Based on these conditions, this research aiming to answer the challenge by performing suitability analysis using public domain tools that are developed specifically to finally be able to produce a water-friendly planning in the Universitas Indonesia Depok catchment area using SUSTAIN model.

Some research on LID has been done before especially focused on the runoff quantity as the decrease of flood discharge and the effectiveness of each type of LID practice separately. However, no specific research has been found which discussed specifically about the site selection to determine the specific type of BMPs to be installed in a CA, especially in UI campus CA. In addition to the scope of the study, the novelty of this research is on the public domain tools used, namely System for Urban Stormwater Treatment and Analysis Integration (SUSTAIN), which is a decision-making tool developed by US Environmental Protection Agency (US EPA) since 2003 [14]. SUSTAIN is a relatively new tool in the analysis of rainwater runoff management, especially in Indonesia.

\section{Method}

\subsection{Framework and Tools of Study}

This study is conducted in 2 (two) main steps, which are; (1) Suitability Analysis, to determine the type of BMPs to be applied/placed in certain location within the UI Campus CA, and (2) Validation Analysis to ensure the result from the suitability analysis which will be cross checked with the actual condition in the field. The location of this study case is in catchment area of UI Campus in Depok as one of the example of urban catchment area.

The tool used for suitability analysis is BMP Siting Tools (BST) module on the SUSTAIN program which is an extension of the ArcGIS software. BMP siting tool is used to assist users in selecting suitable locations for different types of LID (BMP) techniques. 
This tool is implemented using ESRI ArcGIS 9.3 and 10.1 and Spatial Analyst extension $[4,6,11,14]$. This study is using ArcGIS 10.1 for its analysis process.

Validation of SUSTAIN model analysis is performed as the conformity how accurate is the result from BST suitability analysis in accordance with actual conditions in the site. Total twenty points are set as the checking point, whereas the actual condition situation pictures is taken by direct observing and using the information from Google street view as one of the Google maps feature.

\subsection{Study Area Description}

UI Campus in Depok is located at the boundary of Jakarta Special Capital Region and Depok City, West Java Province, Indonesia which geographically located between $6^{0} 20^{\prime} 54^{\prime \prime} \mathrm{N}-6^{0} 23^{\prime} 19^{\prime} \mathrm{S}$ and $106^{\circ} 49^{\prime} \mathrm{E}-106^{\circ} 49^{\prime} 48^{\prime \prime} \mathrm{E}$. The campus area was designed with better landscaping to preserve the topography as well as the water bodies. There are total 8 ponds identified within the UI campus CA, namely Kenanga, Agathis, Mahoni, Puspa, Ulin, and Salam, which existed inside the campus area, and pond of Pladen and Rawa Besar which existed outside of the campus area.

With total catchment area around 580 Hectares, where around 305 Hectares (the northern part) is located inside the campus area, and the rest (the southern part) is located outside campus area [8], the difference of land use condition inside and outside the UI campus in its catchment area is contrasting. As can be seen in Figure 1, whilst most of the land use inside of the campus area are covered with the vegetation, the outside part of the campus is dominated by improperly planned and high density residential areas [8].

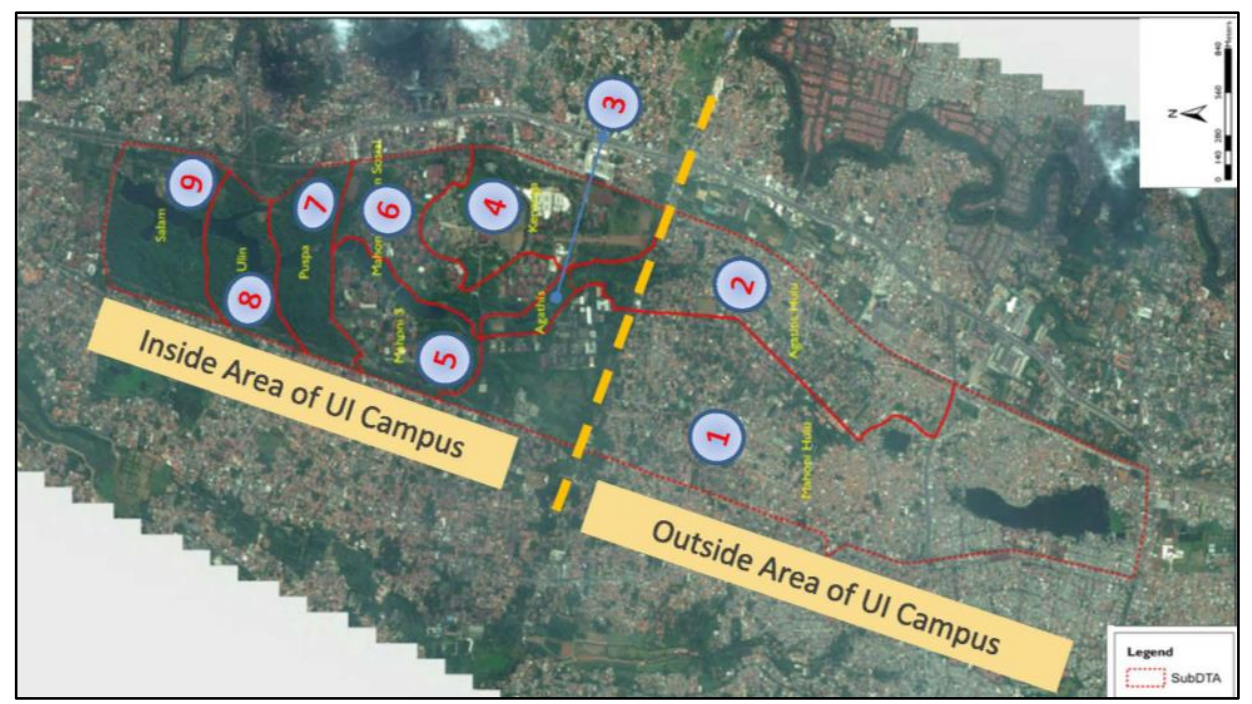

Fig. 1. Sub Catchment Area of Universitas Indonesia Campus, Depok

UI campus CA is divided to 9 (nine) sub catchment area which are (1) Sub CA Mahoni Hulu, (2) Sub CA Agathis Hulu, (3) Sub CA Agathis, (4) Sub CA Kenanga, (5) Sub CA Mahoni 3, (6) Sub CA Mahoni Rumpun Sosial, (7) Sub CA Puspa, (8) Sub CA Ulin, and (9) Sub CA Salam (see Figure 2). The division is done based on the topographical border and the location of the ponds in the CA. This sub CA partition and numbering will be used in the analysis process to get more detailed results especially in the suitability of the BMPs. 


\subsection{Data Requirement}

Data required for this research using BST in SUSTAIN mainly is the thematic map (in raster and shape format) for data layer in ArcGIS. There are nine base data layers required including; slope, soil type, urban land use, percent impervious, land ownership, roads, water table depth, stream location, and drainage area [14], as seen in Table 1.

Table 1. Data Requirement for BMP Siting Tools, SUSTAIN

\begin{tabular}{|c|c|c|c|}
\hline GIS layer & Format & Description & Data Used \\
\hline DEM & $\begin{array}{l}\text { Raster } \\
\text { file }\end{array}$ & $\begin{array}{l}\text { The DEM is used to calculate the drainage } \\
\text { slope and drainage areas that are used to } \\
\text { identify the suitable locations for BMPs. }\end{array}$ & $\begin{array}{l}\text { Topography Map } \\
\text { of Depok City, } \\
\text { Badan } \\
\text { Perencanaan dan } \\
\text { Pembangunan } \\
\text { Daerah, 2012, } \\
\text { scale } 1: 25.000\end{array}$ \\
\hline Land Use & $\begin{array}{l}\text { Raster } \\
\text { file }\end{array}$ & $\begin{array}{l}\text { The land use grid (e.g., NLCD land cover) } \\
\text { is used to eliminate the unsuitable areas for } \\
\text { BMPs. }\end{array}$ & \multirow{5}{*}{$\begin{array}{l}\text { - Land Use Map of } \\
\text { Depok City, } \\
\text { Badan Informasi } \\
\text { Geospasial 2011, } \\
\text { scale 1 : 25.000 } \\
\text { - Google Earth, } \\
\text { Quickbird, 2015 } \\
\text { - Bing Satellite, } \\
\text { Microsoft, } 2016\end{array}$} \\
\hline $\begin{array}{l}\text { Percent } \\
\text { Impervious }\end{array}$ & $\begin{array}{l}\text { Raster } \\
\text { file }\end{array}$ & $\begin{array}{l}\text { The percent impervious grid is used to } \\
\text { identify the suitable locations for BMPs for } \\
\text { the given suitability criteria. }\end{array}$ & \\
\hline $\begin{array}{l}\text { Urban Land } \\
\text { Use }\end{array}$ & $\begin{array}{l}\text { Shape } \\
\text { file }\end{array}$ & $\begin{array}{l}\text { The urban land use data contain the } \\
\text { boundaries for the buildings and the } \\
\text { impervious areas needed to identify suitable } \\
\text { locations for LID elements. }\end{array}$ & \\
\hline Road & $\begin{array}{l}\text { Shape } \\
\text { file }\end{array}$ & $\begin{array}{l}\text { The road layer is used to identify suitable } \\
\text { locations for some BMPs that must be } \\
\text { placed in a specific road buffer area. }\end{array}$ & \\
\hline Stream & $\begin{array}{l}\text { Shape } \\
\text { file }\end{array}$ & $\begin{array}{l}\text { The stream layer is used to define a buffer } \\
\text { so that certain BMP types can be placed } \\
\text { outside the buffer to minimize the impact } \\
\text { on streams. }\end{array}$ & \\
\hline Soil & $\begin{array}{l}\text { Shape } \\
\text { file }\end{array}$ & $\begin{array}{l}\text { The soil data contain the soil properties } \\
\text { such as hydrological soil group, which are } \\
\text { used to identify suitable locations for } \\
\text { BMPs. }\end{array}$ & $\begin{array}{l}\text { Soil Map of Depok } \\
\text { City, Pusat } \\
\text { Penelitian Tanah, } \\
\text { Bogor, } 2011 \text {, scale } \\
1: 25.000\end{array}$ \\
\hline $\begin{array}{l}\text { Groundwate } \\
\text { r Table } \\
\text { Depth }\end{array}$ & $\begin{array}{l}\text { Shape } \\
\text { file }\end{array}$ & $\begin{array}{l}\text { The groundwater table depth layer is used } \\
\text { to identify suitable locations for the } \\
\text { infiltration BMPs; derived from monitoring } \\
\text { data. }\end{array}$ & \\
\hline $\begin{array}{l}\text { Land } \\
\text { Ownership }\end{array}$ & $\begin{array}{l}\text { Shape } \\
\text { file }\end{array}$ & $\begin{array}{l}\text { A parcel layer is used to identify the } \\
\text { locations on the public or private land. }\end{array}$ & \\
\hline
\end{tabular}

Source: [14]

Every each of the data listed are the final format which will be used as one layer. The layer of Percent Impervious, Urban Land Use, and Land Ownership are identified and created from basic data of land use map with the scale of $1: 25.000$, which then digitize referring to Google Earth, Quickbird and Bing Satelite, Microsoft to get the layer map with the scale of $1: 10.000$ as the result.

GIS data input for BST in SUSTAIN required a specific format, type and field type, which is very sensitive for error. Making sure that the data is made properly as required is 
really important in this case. The other highlight is that GIS layers with different coordinate systems will cause errors during the spatial analysis. It is important to project all GIS data into the preferred coordinate system of the study area before starting the project. To project the GIS data from one coordinate system to another, use the Project utility under Data Management Tools of ArcToolbox [14].

Table 2. GIS data format requirement for BMP suitability analysis

\begin{tabular}{|c|c|c|c|c|}
\hline GIS layer & $\begin{array}{l}\text { Data } \\
\text { type }\end{array}$ & Field name & $\begin{array}{l}\text { Field } \\
\text { type }\end{array}$ & Field value/description \\
\hline DEM & Raster & VALUE & Floating & ESRI grid \\
\hline Land Use & Raster & VALUE & Integer & ESRI grid \\
\hline \multirow[t]{3}{*}{$\begin{array}{l}\text { Land Use } \\
\text { Lookup }\end{array}$} & \multirow[t]{3}{*}{ Table } & LUCODE & Integer & $\begin{array}{l}\text { Should be same as in the } \\
\text { VALUE field in Land Use raster } \\
\text { layer }\end{array}$ \\
\hline & & LUNAME & String & $\begin{array}{l}\text { Description about the land use } \\
\text { type }\end{array}$ \\
\hline & & SUITABLE & Short & $\begin{array}{l}1 \text { or } 0(1=\text { suitable; } 0= \\
\text { unsuitable })\end{array}$ \\
\hline$\%$ Impervious & Raster & VALUE & Integer & $0-100$ \\
\hline Soil & Shape & MUKEY & String & $\begin{array}{l}\text { Hydrological soil classification } \\
\text { (STATSGO or SSURGO or } \\
\text { local dataset) }\end{array}$ \\
\hline \multirow[t]{2}{*}{ Soil Lookup } & Table & MUKEY & String & $\begin{array}{l}\text { Should be same as in the } \\
\text { MUKEY field }\end{array}$ \\
\hline & & HYDGRP & String & $\mathrm{A}$ or $\mathrm{B}$ or $\mathrm{C}$ or $\mathrm{D}$ \\
\hline $\begin{array}{l}\text { Urban Land } \\
\text { Use }\end{array}$ & Shape & LU_DESC & String & $\begin{array}{l}\text { Buildings (for Green Roof BMP } \\
\text { type and defining the buffer } \\
\text { around the buildings) or } \\
\text { Roadways or ParkingLots (for } \\
\text { Porous Pavement BMP type) }\end{array}$ \\
\hline Road & Shape & N/A & N/A & $\mathrm{N} / \mathrm{A}$ \\
\hline Stream & Shape & $\mathrm{N} / \mathrm{A}$ & $\mathrm{N} / \mathrm{A}$ & $\mathrm{N} / \mathrm{A}$ \\
\hline $\begin{array}{l}\text { Groundwater } \\
\text { Table Depth }\end{array}$ & Shape & GWDEP_FT & Double & Depth to groundwater table \\
\hline $\begin{array}{l}\text { Land } \\
\text { Ownership }\end{array}$ & Shape & OWNERSHIP & String & Public or Private \\
\hline
\end{tabular}

Source: [14]

\subsection{Suitability Parameter}

Suitability analysis performed by setting the criteria for all nine parameters which considered to be appropriate for each type of BMPs. The criteria used in this research mainly is based on the default criteria derived from the BMP Siting Tools User Guide, which refers to two of US EPA reports in 2004, which is shown in Table 3 [14].

These criteria can be adjusted to our preference based on local knowledge and situation, though the parameter of column (5), (7), (8), and (9) have a limited option, whereas we need to select the option which already been offered (e.g for building buffer some of the options are $<30,30-50,50-100$, or $>100$ ), and can not be filled with a random number nor alphabet. As for the other columns, the limitation is off and can be adjusted with any number needed [14].

Based on the local situation in research site, some modification was made for some of BMPs suitability criteria. The default criteria made by US EPA in the BST guide book 
mostly based on the site condition in the United State of America, whereas having a lower density of urban area compared to Indonesia. This modification crossed checked by referring to the consideration of BMPs guidelines [1]. The changes made are;

- Porous pavement; suitability criteria for slope $=<5 \%$

- Rain barrel; suitability criteria for building buffer $=50-100 \mathrm{ft}$

- Vegetated filterstrip; suitability criteria for road buffer $=50-100 \mathrm{ft}$

Table 3. Default Criteria for each Parameter in BMP Siting Tool, SUSTAIN

\begin{tabular}{|c|c|c|c|c|c|c|c|c|}
\hline BMP Type & $\begin{array}{c}\text { Drain- } \\
\text { age } \\
\text { Area } \\
\text { (acre) }\end{array}$ & $\begin{array}{c}\text { Drain- } \\
\text { age } \\
\text { Slope } \\
\text { (\%) }\end{array}$ & $\begin{array}{c}\text { Imper- } \\
\text { vious } \\
(\%)\end{array}$ & HSG & $\begin{array}{c}\text { Water } \\
\text { table } \\
\text { depth } \\
\text { (ft) }\end{array}$ & $\begin{array}{c}\text { Road } \\
\text { Buffer } \\
\text { (ft) }\end{array}$ & $\begin{array}{c}\text { Stream } \\
\text { Buffer } \\
\text { (ft) }\end{array}$ & $\begin{array}{c}\text { Build- } \\
\text { ing } \\
\text { Buffer } \\
\text { (ft) }\end{array}$ \\
\hline $\begin{array}{c}\text { Bioretention } \\
\text { (Br) }\end{array}$ & $<2$ & $<5 \%$ & $>0 \%$ & A-D & $>2$ & $<100$ & $>100$ & -- \\
\hline Cistern (Cs) & -- & -- & -- & -- & -- & -- & -- & $<30$ \\
\hline $\begin{array}{c}\text { Constructed } \\
\text { Wetland (Cw) }\end{array}$ & $>25$ & $<15 \%$ & $>0 \%$ & A-D & $>4$ & -- & $>100$ & -- \\
\hline Dry Pond (Dp) & $>10$ & $<15 \%$ & $>0 \%$ & A-D & $>4$ & -- & $>100$ & -- \\
\hline $\begin{array}{c}\text { Grassed Swale } \\
\text { (Gs) }\end{array}$ & $<5$ & $<4 \%$ & $>0 \%$ & A-D & $>2$ & $<100$ & -- & - \\
\hline Green Roof (Gr) & -- & -- & -- & -- & -- & -- & -- & V \\
\hline $\begin{array}{c}\text { Infiltration } \\
\text { Basin (Ibs) }\end{array}$ & $<10$ & $<15 \%$ & $>0 \%$ & A-B & $>4$ & -- & $>100$ & -- \\
\hline $\begin{array}{c}\text { Infiltration } \\
\text { Trench (Itr) }\end{array}$ & $<5$ & $<15 \%$ & $>0 \%$ & A-B & $>4$ & -- & $>100$ & -- \\
\hline $\begin{array}{c}\text { Porous } \\
\text { Pavement (Pp) }\end{array}$ & $<3$ & $<1 \%$ & $>0 \%$ & A-B & $>2$ & -- & -- & -- \\
\hline $\begin{array}{c}\text { Rain Barrel } \\
\text { (Rb) }\end{array}$ & -- & -- & -- & -- & -- & -- & -- & $<30$ \\
\hline $\begin{array}{c}\text { Sand Filter non- } \\
\text { surface (Sfns) }\end{array}$ & $<2$ & $<10 \%$ & $>0 \%$ & A-D & $>2$ & -- & $>100$ & -- \\
\hline $\begin{array}{c}\text { Sand Filter } \\
\text { surface (Sfs) }\end{array}$ & $<10$ & $<10 \%$ & $>0 \%$ & A-D & $>2$ & -- & $>100$ & -- \\
\hline $\begin{array}{c}\text { Vegetated } \\
\text { Filterstrip (Vfs) }\end{array}$ & -- & $<10 \%$ & $>0 \%$ & A-D & $>2$ & $<100$ & -- & - \\
\hline Wet Pond (Wp) & $>25$ & $<15 \%$ & $>0 \%$ & A-D & $>4$ & -- & $>100$ & -- \\
\hline
\end{tabular}

The assumption used in this study is for the water table depth data, due to limited data availability, which is $4 \mathrm{~m}(13,12 \mathrm{ft})$. The geology formation for the CA is Qav formation (Alluvial Fan) which consist of bedded fine tuff, sandy tuff, inter bedded with conglomeratic tuff, thus the water table depth is assumed to be the same for all of the CA. Furthermore, the study area is relatively a small area and flat.

\subsection{Operating BMP Siting Tools}

The suitability analysis operated by BMP Siting Tools (BST) in SUSTAIN is done in three steps. The data specified are entered simultaneously in the Data Management tab of the BST module is the first step. Then, the next step is to select the type of BMPs to be analyzed, by moving the wanted BMP type on the left box to the right box. These 2 steps shown in Figure 2. Total fourteen of BMPs type are provided in BST. In this study, all types of BMPs listed are included as an alternative, nonetheless, the Cistern is opted out as it is considered has the similar function with rain barrel but requires a bigger area. 

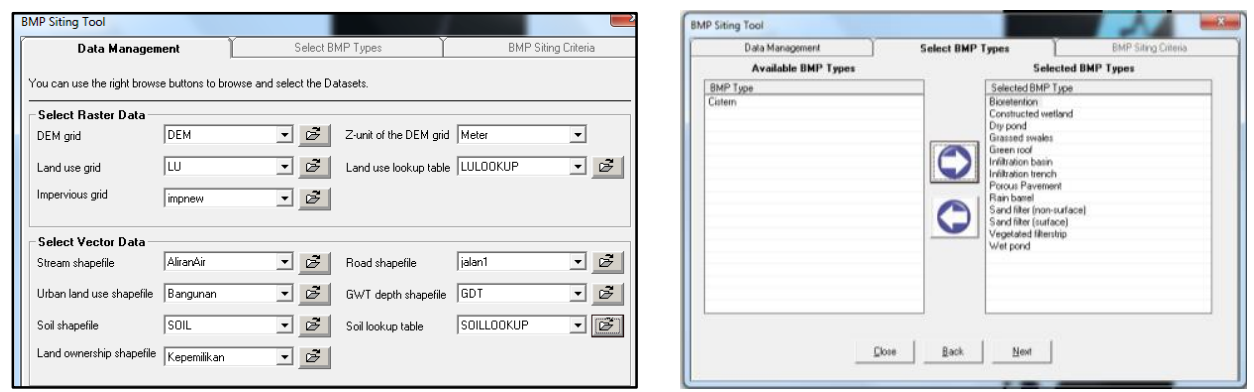

Fig. 2. Step 1 Filling Data Management (left); and Step 2 Selecting BMP Types (right), BMP Siting Tool, SUSTAIN [14]

After selecting the BMPs type, the next step needed is to establish the siting criteria by entering the parameter values that have been set as in Table 3. Select the BMPs type one by one, then fill in the criteria. This step is done repeatedly for each type of BMPs that will be assessed. Figure 3 shows the example of setting the criteria for Bioretention.

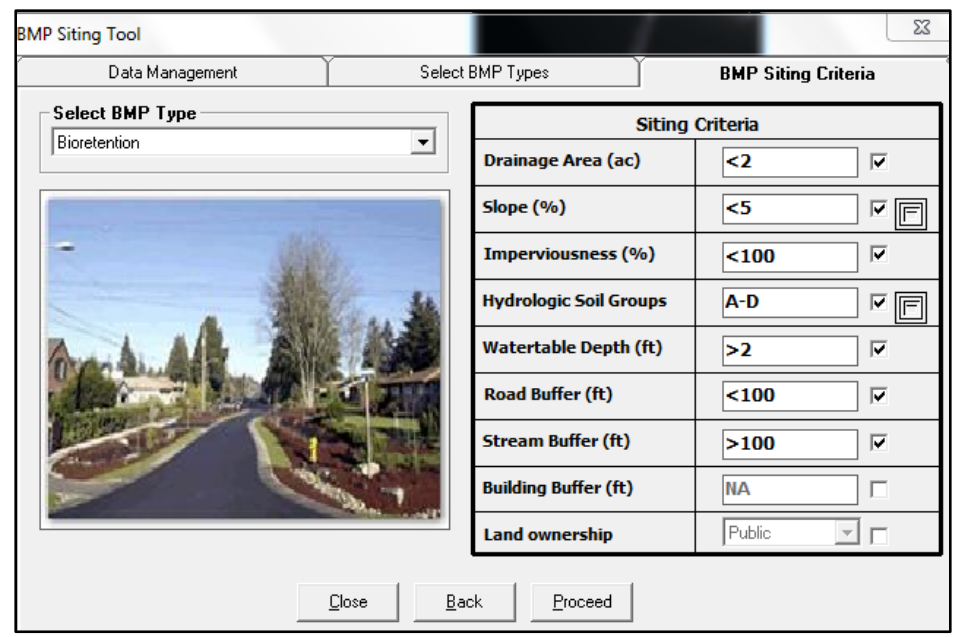

Fig. 3. BMP Siting Criteria, BMP Siting Tool, SUSTAIN [14]

Make sure to click the proceed button only after finishing all the criteria for all type of BMPs. The output from BMP Siting Tool Analysis is a spatial map that marks areas in the CA that meet the standards or that meet the specified criteria required.

\section{Result and Discussion}

\subsection{Distribution of BMPs}

The BST executed to perform BMPs suitability analysis is performed simultaneously at one time for each selected BMPs. Suitability analysis using SUSTAIN BST shows that there are 10 types of BMPs that are suitable to be placed in UI Depok catchment area, namely; (1) Bioretention; (2) Green Roof; (3) Porous Pavement; (4) Vegetated Filterstrip; (5) Grassed Swale, (6) Rain Barrel, (7) Infiltration Trench, (8) Infiltration Basin, (9) Sand Filter surface, and (10) Sand filter non-surface. 
The output of BST is the layers showing the location for each one of BMPs type and a layer of composite map showing all of the combination of suitable BMP types at each location. The distribution of location and type of BMPs of this suitability analysis is presented in Figure 4. The result of this suitability analysis also shows that green infrastructure in the upstream area still has the potential to be developed, although it is not continuous (still segmented) as situated in a dense residential area. The green line from Situ Rawa Besar located on the upstream of CA can be connected to the downstream (Lake Agathis on UI campus or Situ Pladen) by following the middle channel of CA, by applying Bioretention, Grassed Swale and Vegetated Filterstrip types

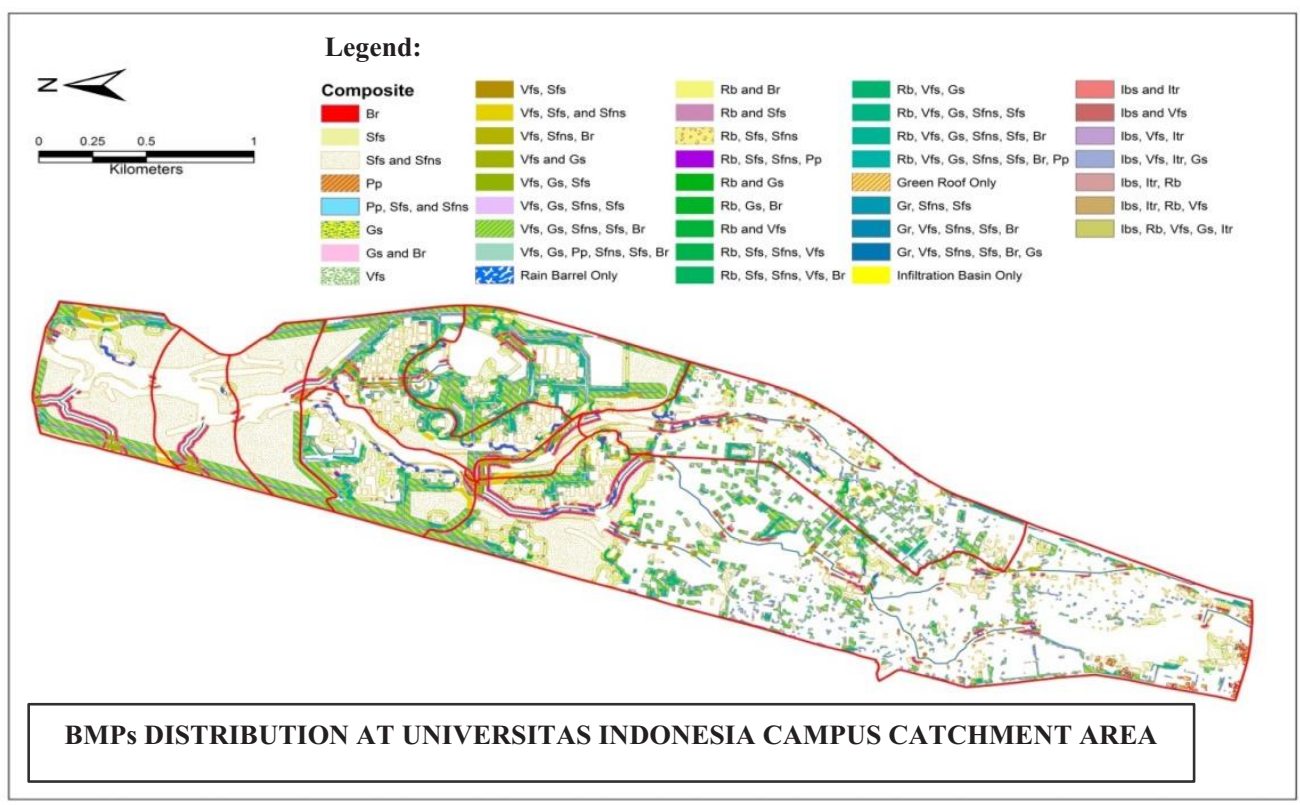

Fig. 4. Composite Result of BMPs Distribution in Universitas Indonesia Depok Catchment Area

\subsection{BMPs Suitability and Validation}

Analysis of the suitability of BMP types to the locations within the UI Depok CA illustrates that certain types of BMP have a higher suitability compared to other types of BMPs in terms of the number of appropriate Sub CA (see Table 4).

Types of BMPs of constructed wetland, dry pond and wet pond are not suitable to be installed in any sub CA of UI Depok. From the simulation process, the cause of the nonsuitable BMPs is found in drainage area and the water table depth parameter, whereas the type of non-suitable BMPs requires a large area, like dry pond and constructed wetland.

The validation step is performed by determining 20 observation points as sample, scattered and representing all nine sub CA. The result from suitability analysis by SUSTAIN model are then validated with actual conditions in the field, thus the validation result will come as applicable or not applicable. From total 20 observation points, 18 points are applicable, while 1 point is not applicable and 1 other point is still applicable but not maximum. Table 5 shows some of the example of the validation process and findings from total 20 observation points. 
Table 4. BMPs Suitability for Each Sub Catchment Area

\begin{tabular}{|c|c|c|c|c|c|c|c|c|c|c|}
\hline \multicolumn{2}{|c|}{ Sub Catchment Area Code Number } & 1 & 2 & 3 & 4 & 5 & 6 & 7 & 8 & 9 \\
\hline \multirow{13}{*}{$\sum_{\substack{\infty \\
\infty}}^{\stackrel{0}{n}}$} & Bioretention (Br) & $\sqrt{ }$ & $\sqrt{ }$ & $\sqrt{ }$ & $\sqrt{ }$ & $\sqrt{ }$ & $\sqrt{ }$ & $\sqrt{ }$ & $\sqrt{ }$ & $\sqrt{ }$ \\
\hline & Constructed Wetland (Cw) & $x$ & $x$ & $x$ & $x$ & $x$ & $x$ & $x$ & $x$ & $x$ \\
\hline & Dry Pond (Dp) & $x$ & $x$ & $x$ & $x$ & $x$ & $x$ & $x$ & $x$ & $x$ \\
\hline & Grassed Swale (Gs) & $\sqrt{ }$ & $\sqrt{ }$ & $\sqrt{ }$ & $\sqrt{ }$ & $\sqrt{ }$ & $\sqrt{ }$ & $\sqrt{ }$ & $\sqrt{ }$ & $\sqrt{ }$ \\
\hline & Green Roof $(\mathrm{Gr})$ & $\sqrt{ }$ & $x$ & $x$ & $x$ & $x$ & $x$ & $x$ & $x$ & $x$ \\
\hline & Infiltration Basin (Ibs) & $\sqrt{ }$ & $\sqrt{ }$ & $\sqrt{ }$ & $\sqrt{ }$ & $\sqrt{ }$ & $\sqrt{ }$ & $\sqrt{ }$ & $\sqrt{ }$ & $\sqrt{ }$ \\
\hline & Infiltration Trench (Itr) & $\sqrt{ }$ & $\sqrt{ }$ & $\sqrt{ }$ & $\sqrt{ }$ & $\sqrt{ }$ & $\sqrt{ }$ & $\sqrt{ }$ & $\sqrt{ }$ & $\sqrt{ }$ \\
\hline & Porous Pavement $(\mathrm{Pp})$ & $x$ & $x$ & $x$ & $\sqrt{ }$ & $\sqrt{ }$ & $\sqrt{ }$ & $x$ & $x$ & $x$ \\
\hline & Rain Barrel $(\mathrm{Rb})$ & $\sqrt{ }$ & $\sqrt{ }$ & $x$ & $\sqrt{ }$ & $\sqrt{ }$ & $\sqrt{ }$ & $x$ & $\sqrt{ }$ & $\sqrt{ }$ \\
\hline & Sand Filter (non-surface) (Sfns) & $\sqrt{ }$ & $\sqrt{ }$ & $\sqrt{ }$ & $\sqrt{ }$ & $\sqrt{ }$ & $\sqrt{ }$ & $\sqrt{ }$ & $\sqrt{ }$ & $\sqrt{ }$ \\
\hline & Sand Filter (surface) (Sfs) & $\sqrt{ }$ & $\sqrt{ }$ & $\sqrt{ }$ & $\sqrt{ }$ & $\sqrt{ }$ & $\sqrt{ }$ & $\sqrt{ }$ & $\sqrt{ }$ & $\sqrt{ }$ \\
\hline & Vegetated Filterstrip (Vfs) & $\sqrt{ }$ & $\sqrt{ }$ & $\sqrt{ }$ & $\sqrt{ }$ & $\sqrt{ }$ & $\sqrt{ }$ & $\sqrt{ }$ & $\sqrt{ }$ & $\sqrt{ }$ \\
\hline & Wet Pond (Wp) & $x$ & $x$ & $x$ & $x$ & $x$ & $x$ & $x$ & $x$ & $x$ \\
\hline
\end{tabular}

Note : $(\sqrt{ })$ Suitable; $(\times)$ Not Suitable

Table 5. Sample of Validation of BMPs Suitability

\begin{tabular}{|c|c|c|c|c|c|}
\hline $\begin{array}{l}\text { Point } \\
\text { No }\end{array}$ & $\begin{array}{c}\text { Sub CA } \\
\text { Number } \\
\text { Code }\end{array}$ & $\begin{array}{c}\text { BMPS's } \\
\text { Suitability } \\
\text { Result }\end{array}$ & Actual Condition & Picture & Validation \\
\hline 1 & 1 & Sfs, Sfns & Building, grassy yard & & Applicable \\
\hline 2 & 2 & $\mathrm{Br}$, Vfs, Sfs, Gs & Vegetation & & Applicable \\
\hline 3 & 4 & Sfs, Pp & $\begin{array}{c}\text { Grassed Cover, Open } \\
\text { Space }\end{array}$ & & Applicable \\
\hline 4 & 6 & $\mathrm{Br}$, Vfs, Sfs, Gs & $\begin{array}{l}\text { Building, road, } \\
\text { vegetation }\end{array}$ & & $\begin{array}{l}\text { Applicable, not } \\
\text { Maximum }\end{array}$ \\
\hline 5 & 7 & $\mathrm{Br}, \mathrm{Vfs}$ & $\begin{array}{l}\text { Vegetation and } \\
\text { Building }\end{array}$ & & Not Applicable \\
\hline
\end{tabular}

The validation for point 5, BST model shows that the area is suitable for Bioretention and/or Vegetated Filterstrip. The actual condition for this area is the parking yard with a full pavement, which is not applicable for those type of BMPs. In this case, SUSTAIN may identify the area as an open space caused by the scale of the map or data input.

\section{Conclusion}

Suitability analysis using SUSTAIN BST shows that there are 10 types of BMPs that are suitable to be placed in UI Depok catchment area. The type of BMPs which are not suitable, including constructed wetland, wet pond and dry pond, mainly caused by the limited availability of land. As the type of suitable BMPs are still dominant in this case, this study shows that LID concept can be applied in UI campus CA with high possibilities. 
Based on the validation analysis, the applicable result from SUSTAIN model is 18 of 20, or has $90 \%$ level of trust. Thus, this model is proper to be used and applied for a suitability analysis for BMPs placement. For further study, using the large scale of map as data input is highly recommended for a better result.

\section{Acknowledgment}

The author would like to thank Universitas Indonesia for the financial support for this study through the PITTA 2017 funding scheme under grant no. 857/UN2.R3.1/HKP.05.00/2017, managed by the Directorate for Research and Public Service, Universitas Indonesia. Special thanks to Dr. Rer. Nat. Eko Kusratmoko and Chandra Pradana from Department of Geography, Universitas Indonesia for providing the geospatial data, the member of Hydraulic, Hydrology and River Engineering Laboratory for the support accordingly, and to Wisnu Tri Winarendro for the troubleshooting related to SUSTAIN software during the process of this study.

\section{References}

1. Applied Ecological Services, Inc, Alternative Stormwater Best Management Practices Guidelines (Public Works and Utilities Department Watershed Management Division City Of Lincoln, Eudora, 2006)

2. Badan Perencanaan, Pengembangan dan Pengendalian Universitas Indonesia (BP3UI), Persiapan Audit Kesehatan Perairan dan DTA Kampus UI Depok (BP3UI, Depok, 2015)

3. Center for Watershed Protection, Watershed Protection Research Monograph No.1: Impacts of Impervious Cover On Aquatic Systems (Center for Watershed Protection, Ellicott City, 2003).

4. C. Chen, M. Sheng, C. Chang, S. Kang, J. Lin, Jour. Water. 6, 3575 (2014)

5. C. Arnold, C. Gibbons, Jour. Amr. Plan. Ass. 62, 243 (1996)

6. C. Viriyadhika, I. Kustiwan, J. Prc. Wil. Kot. 3, 239 (2014)

7. D. Theobald, S. Goetz, J. Norman, P. Jantz, Jour. Hydrol. Eng. 14, 362 (2009)

8. D. Sutjiningsih, Int. Jour. Tech. 1, 145 (2017)

9. E. Brabec, S. Schulte, P. Richards, Jour. Plan. Lit. 16, 499 (2002)

10. J. Lee, A. Selvakumar, K. Alvi, J. Riverson, J. Zhen, L. Shoemaker, F. Lai, Jour. Env. Mod. Soft. 37, 6 (2012)

11. L. Shoemaker, J. Riverson, K. Alvi, J. Zhen, R. Murphy, Tetra Tech, Inc., Report on Enhanced Framework (SUSTAIN) and Field Applications for Placement of BMPs in Urban Watershed (U.S Environmental Protection Agency, Cincinnati, 2011)

12. P. Flinker, The Need to Reduce Impervious Cover to Prevent Flooding and Protect Water Quality (Dodson Associates, Ltd., Ashfield, 2010)

13. S. Muthukrishnan, B. Madge, A. Selvakumar, R. Field, D. Sullivan, The Use of Best Management Practices (BMPs) in Urban Watershed (U.S Environmental Protection Agency, Cincinnati, 2004)

14. Tetra Tech, Inc, BMP Siting Tool: Step by Step Guide, ArcGIS 10.1 Service Pack 1 (Tetra Tech, Inc, Fairfax, 2013)

15. T. Schueler, L. McNeal, K. Cappiella, Jour. Hydrol. Eng. 14, 309 (2009) 